\title{
OR10-002 - A novel TNFR1 transcript of TRAPS gene
}

\author{
C Rittore ${ }^{1}$, E Sanchez ${ }^{1}$, S Soler ${ }^{1}$, M Albers ${ }^{2}$, L Obici $^{3}$, MF McDermott ${ }^{4}$, I Touitou' ${ }^{1}$ S Grandemange ${ }^{\text {** }}$ \\ From 7th Congress of International Society of Systemic Auto-Inflammatory Diseases (ISSAID) \\ Lausanne, Switerland. 22-26 May 2013
}

\section{Introduction}

Mutations in the TNFRSF1A gene encoding the TNF cell surface receptor, TNFR1, cause TNFR-associated periodic syndrome (TRAPS) and polymorphisms in TNFRSF1A, including rs4149570, rs767455 and rs1800692, are associated with inflammatory diseases.

\section{Objectives}

We describe a novel exon 2-spliced transcript, named TNFR1-d2, and the impact of these 3 SNPs on exon 2 splicing, transcriptional activity of TNFRSF1A and TRAPS phenotype.

\section{Methods}

Expression of TNFRSF1A transcripts was performed by RT-PCR in a range of human cells and tissues. Exon 2 splicing and transcriptional activity were analysed in HEK293T and SW480 cells by in vitro alternative splicing and luciferase assays, respectively. We constructed haplotypes containing rs4149570, rs767455 and rs1800692 in controls $(\mathrm{n}=70)$, TRAPS $(\mathrm{n}=111)$ and TRAPS-like patients $(n=450)$ to compare their distribution and association with clinical features of TRAPS.

\section{Results}

TNFR1-d2 was expressed in a tissue-specific manner, whereas TNFR1 expression was ubiquitous. Alternative splicing assays revealed that the T-A-T haplotype at rs4149570-rs767455-rs1800692 showed the highest expression of exon 2-skipping product ( $\mathrm{p}=0.02)$. Transcriptional activity from the T-T haplotype at rs4149570rs1800692 was increased compared to the G-C haplotype $(\mathrm{p}=0.03)$. In TRAPS patients, $\mathrm{rs} 1800692 \mathrm{~T} / \mathrm{T}$ homozygotes were excessively rare $\left(\mathrm{p}<10^{-4}\right)$ and TRAPS-like patients with this genotype experienced less fever.

${ }^{1}$ INSERM / CHU A.DE VILLENEUVE, Montpellier, France

Full list of author information is available at the end of the article

\section{Conclusion}

Our study provides a novel mechanism of TNFRSF1A regulation whereby three polymorphisms in the promoter, exon 1 and intron 4 have a functional and combined effect on exon 2 splicing, via a coupling mechanism between transcription and splicing. These polymorphisms may impact the phenotype of TRAPS and TRAPS-like patients.

\section{Competing interests}

None declared.

\section{Authors' details}

${ }^{1}$ INSERM / CHU A.DE VILLENEUVE, Montpellier, France. ${ }^{2}$ University Medish Centrum, Utrecht, Netherlands. ${ }^{3}$ IRCCS Fundazion Policlinico San Matteo, Pavia, Italy. ${ }^{4} 6$. NIHR-Leeds Musculoskeletal Biomedical Research Unit, Leeds, UK.

Published: 8 November 2013

doi:10.1186/1546-0096-11-S1-A186

Cite this article as: Rittore et al:: OR10-002 - A novel TNFR1 transcript of TRAPS gene. Pediatric Rheumatology 2013 11(Suppl 1):A186. and take full advantage of:

- Convenient online submission

- Thorough peer review

- No space constraints or color figure charges

- Immediate publication on acceptance

- Inclusion in PubMed, CAS, Scopus and Google Scholar

- Research which is freely available for redistribution 